\title{
長期データを用いた那珂川からの土砂供給量の 推定と河口域での土砂の挙動に関する研究 \\ RESEARCH OF SEDIMENT TRANSPORT BEHAIVIOUR OFF THE RIVERMOUTH AND THE ESTIMATION OF SEDIMENT TRANSPORT QUANTITY FROM THE NAKA RIVER BY USING LONG-PERIOD OBSERBATION DATA
}

\author{
高橋 誠 1 戸戸屋 裕亮 ${ }^{2}$ - 山田 航 $^{3}$ - 荒木 陽介 ${ }^{4}$ - 堀口 真弥 ${ }^{5}$ 田井 $\quad$ 明 ${ }^{6} \cdot$ \\ 松本 健作7 ・鵜㟝 賢一8・清水 義彦9 \\ Makoto TAKAHASHI, Yusuke TOYA, Wataru YAMADA, Yosuke ARAKI, Shinya \\ HORIGUCHI, Akira TAI, Kensaku MATSUMOTO, Ken-ichi UZAKI and Yoshihiko SHIMIZU \\ 1非会員＼cjkstart群馬大学理工学部環境創生理工学科（テ376-8515 群馬県桐生市天神町1-5-1） \\ 2非会員 埼玉県庁（广330-9301 埼玉県さいたま市浦和区高砂3-15-1） \\ 3非会員 茨城県庁（兵310-8555 茨城県水戸市笠原町978-6）
4, 5 非会員 群馬大学大学院理工府環境創生理工学専攻 （テ376-8515 群馬県桐生市天神町1-5-1）
6 正会員 博 (工） 九州大学助教 高等研究院（广819-0395福岡市西区元岡744） \\ 7 正会員 群馬大学理工学研究院環境創生部門 助教, 8 正会員 群馬大学理工学研究院環境創生部門 准 \\ 教授, 9正会員 群馬大学理工学研究院環境創生部門 教授
}

\begin{abstract}
Quantity of Sediment transport from the rivermouth is not well known. However, it is very important in order to calculate sediment transport and beach profile change in coastal zone. Many research activities by using ADCP to estimate sediment transport quantity were made. However, it is difficult to conduct field observations by using ADCP at the flood. Then, in this study, sediment transport quantity form the Naka River in the Ibaraki prefecture was estimated by using ADCP, the turbidity meter, and STD. Furthermore, sediment transport off the rivermouth was observed. In conclusion, the sediment transport quantity due to suspended component was well estimated and it was carried to the direction of southwest, the port of Ooarai.
\end{abstract}

Key Words : sediment transport, rivermouth, ADCP, turbidity meter, STD

\section{1.はじめに}

茨城県の鹿島灘の海岸侵食は全域的に深刻な状況であ る一方で，鹿島港における航路埋没もまた深刻な課題で ある. 宇多ら ${ }^{1)}$ は，那珂川河口の大洗磯浜海岸の侵食状 況を調へ，那珂川の供給土砂の減少をその原因として挙 げているが，供給量の減少について直接的な裏付けはな い. また，こうした侵食対策や航路埋没の対策を広域的 に検討寸るための境界条件としても，那珂川からの土砂 供給量を把握することは非常に重要である。しかしなが ら, 河川の流量データは存在していても土砂供給量の データはあまりないのが現状である，とくに実測值は皆 無であり，掃流砂，浮遊砂・ウオッシュロードを含めて 土砂供給量を精確に計測し，併せてそれらの沿岸域での 挙動を推定することが本研究の目的である. 本論文では,
浮遊砂・ウオッシュロード成分についての検討を行う. 土砂供給量については，橘田ら²)のようにADCPを用 いて河道横断面の流速と後方散乱強度計測を利用寸る方 法が広まりつつあるが，その方法だと横断面全域の流速 分布・土砂濃度分布がわかるものの, 出水ピーク時の観 測が困難である．的確にピーク時の土砂供給量を計測す るためには，重田ら ${ }^{3)}$ のように濁度計の長期係留による 観測が有効であるが，濁度計単体の計測では横断面の分 布に関する情報に乏しい，そこで本研究では，両者の観 測を行ってその結果を複合的に用いて那珂川からの土砂 供給量を算定するとともに，その河口沖での挙動に関し ても明らかにする.

\section{2. 現地観測の概要}


本研究の観測は, 図-1に示寸茨城県の那珂川河口周辺 で行った． 観測方法は河口近傍の海門橋においてADCP （超音波流速計，RD Instruments社製Workhorse）とGPS， 観測船を用いて横断面の流速・後方散乱強度分布を計測 するとともに，バンドーンを用いて採水を行った。また， 海門橋からやや上流に位置寸る茨城海技学院の栈橋に濁 度計（JFEアレック社製Compact-CLW）を長期係留させ 濁度データを取得した。設置水深は水面下 $50 \mathrm{~cm}$ とた。 $\mathrm{ADCP}$ による観測および採水は2012年10月9日・11月 13 日に，濁度計の係留期間は2012年10月11日〜12月1日 ・ 2012年12月27日〜2013年1月23日に行われた。観測期間 ならびに得られた観測データの一覧を表-1に示す，なお， 以降の本論文では，河川水にはプランクトン類が少ない と仮定して，SS濃度を浮遊砂・ウォッシュロード濃度と みなして検討を行っている.

\section{3. 観測結果ならびに考察}

\section{（1）濁度，流量，潮位，雨量の関係}

観測結果の一例として、2012年11月12日から11月19日 までの濁度計のデータを図-2に，潮位（大洗）と流量の 関係を図-3に, 雨量 (水戸・那須) と流量の関係を図-4 に示す。また，流量データに関しては，那珂川河口の湊 大橋水位観測所では水位のみのデータしかなかったため, 河口から約 $40 \mathrm{~km}$ 上流の野口水位観測所での流量データ を用いる. 観測所の位置関係を図一7に示す.

海門橋は河口域にあり, 感潮域であるため, 図-3に示 寸潮位変動の影響を受ける. それは水位上昇とともに塩 水楔の侵入として現れる. 図一において, 青線が濁度, 赤線がchl.a濃度を示すが, 河川水にはプランクトン類は 少なく, 海水に多いことを考えると, 濁度とchl.濃度が 同時に上昇するイベントは塩水楔によるものである。こ れは, $\mathrm{ADCP}$ 計測データからも明らかであり, 流量と 潮時によっては水表面近傍まで楔が占める. 従って, chl.a濃度が上昇せず, 濁度が上昇するケース, 図-2にお いては18日のケースに注目寸る.図-4においては，18日 未明に出水があったこと, また, その直前に上流の那須, 下流の水戸で降雨があったことがわかる. これらの結果

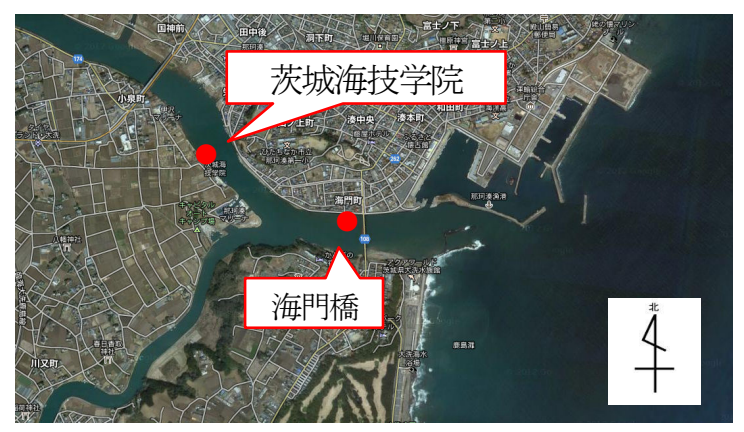

図-1 観測位置(出典 : Google Earth)
からも，この濁度の上昇が出水によるものであること がわかる．19日にも同様のピークが認められるが，いず れも下げ潮時に観測されており, 出水量と潮位の関係で 濁度単体のピークが出現することがわかる.ここで図-2, 図-4において, 出水が大きく, より変化が鮮明でわかり やすい箇所を, 図-5, 図-6として記載する。 また, 図-2, 図-5において極端に值が大きくなっている箇所が見受け られる.これはゴミなどがロープに絡まったことによる, 正しい観測の值とは考えられないスパイクだと判断し, 今回の考察では無視するものとする.

表-1＼cjkstart観測期間と得られたデータ

\begin{tabular}{|c|c|c|}
\hline & 観測期間 & データ \\
\hline $\mathrm{ADCP}$ & $\begin{array}{l}\text { 2012年10月9日 } \\
\text { 2012年11月13日 }\end{array}$ & $\begin{array}{c}\text { 流速 } \\
\text { 後方散乱強度 }\end{array}$ \\
\hline 採水 & & $\begin{array}{l}\text { 質量濃度 } \\
\text { 粒度分布 }\end{array}$ \\
\hline 濁度計 & $\begin{array}{c}\text { 2012年10月 } 11 \text { 日 } \\
\text { 2012年12月 } 1 \text { 日 } \\
\text { 2012年12月 } 27 \text { 日 } \\
\sim 2013 \text { 年1月 } 23\end{array}$ & $\begin{array}{l}\text { 濁度 } \\
\text { Chl.a }\end{array}$ \\
\hline
\end{tabular}

表-2 ADCPの設定

\begin{tabular}{|l|l|}
\hline 測定モード & WMI \\
\hline 測定間隔 & $0.3 \mathrm{~m}$ \\
\hline ビームの発射数 & 3 \\
\hline
\end{tabular}

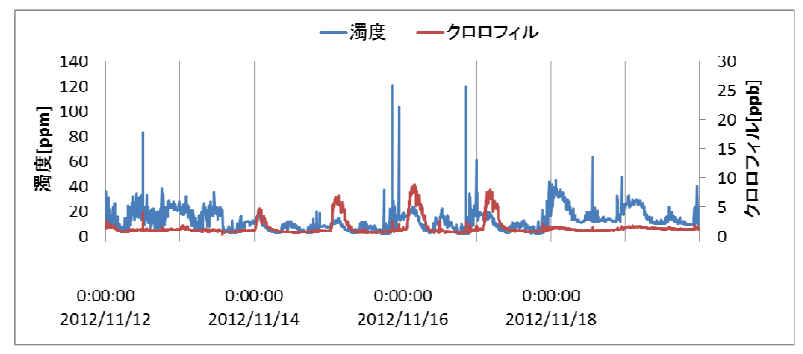

図-2 濁度とchl. a濃度

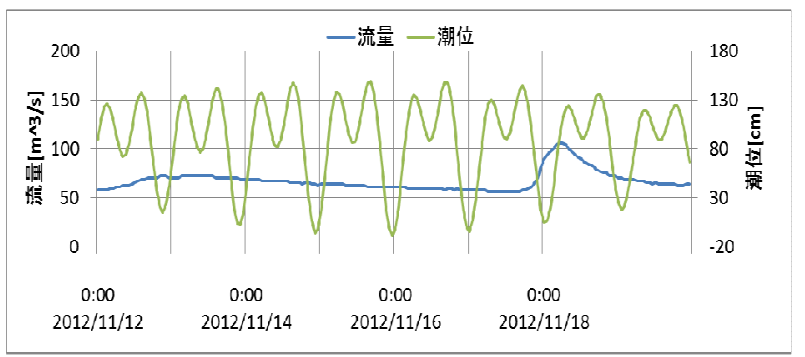

図-3 潮位 (大洗) と流量の関係 


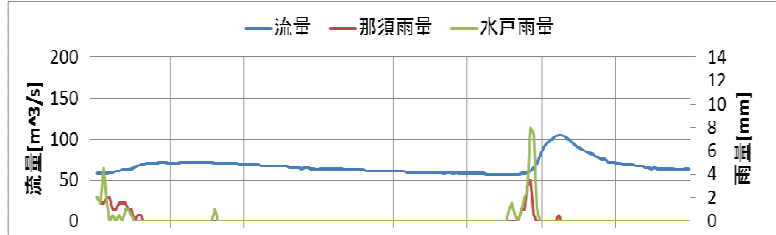

$\begin{array}{cccc}0: 00 & 0: 00 & 0: 00 & 0: 00 \\ 2012 / 11 / 12 & 2012 / 11 / 14 & 2012 / 11 / 16 & 2012 / 11 / 18\end{array}$

図-4 雨量(水戸 · 那須) と流量の関係

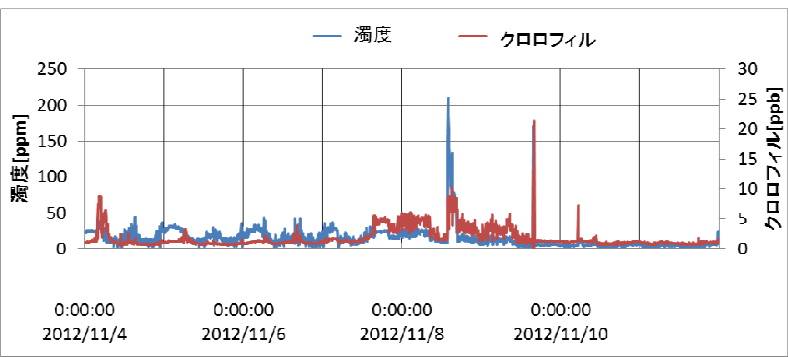

図-5＼cjkstart濁度とchl. a濃度

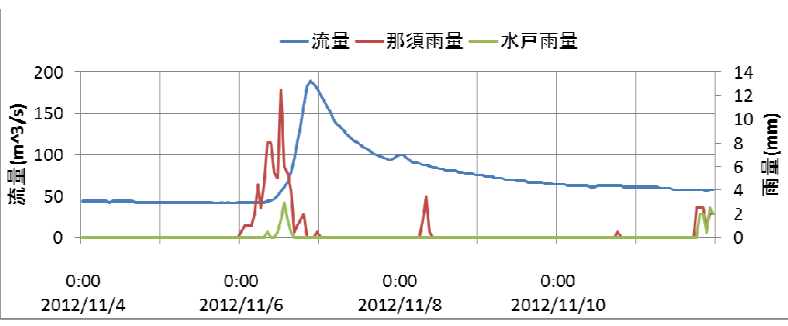

図-6 雨量(水戸 · 那須) と流量の関係

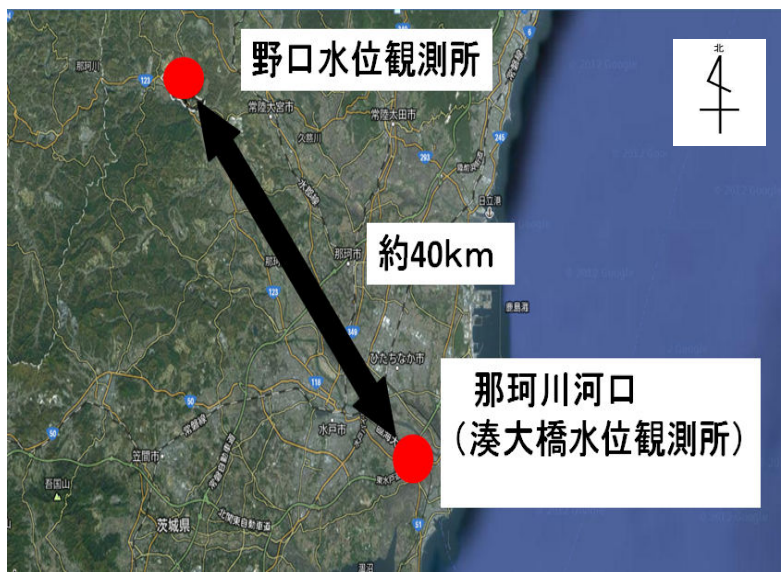

図-7 那珂川観測所の位置(出典 : Google Earth)

\section{（2）ADCPによる流速計測ならびに土砂濃度推定}

図-8に，ADCPによる横断面の流速分布の一例を示す。 図は，10月9日の上げ潮時のものであり，右側が左岸， 左側が右岸である. 暖色が下流方向の東向き, 寒色が上 流方向の西向き流速成分である. 図から，表面ならびに
底面近傍は音波の反射のために流速計測ができないもの の，水深 $1 \mathrm{~m}$ 以浅で下流方向，それ以深では上流向きの 流れが生じており，後者は塩水楔であることがわかる. これはSTDを用いた観測結果の図-9からも，後者が塩水 楔であることがわかる. 図-9にSTDで得られた観測時の 水温・塩分濃度・濁度の鉛直分布を示寸．黄緑のプロッ 卜が水温, 青が塩分濃度, 赤が濁度を表す. 水深 $2 \mathrm{~m}$ 以 降で塩分濃度と水温が上昇しており，海水が存在してい ることが分かる．濁度は，表層の河川水部分が低く，深 層の海水部分が高い結果となっている。これは，海水は 河川水に比べ，クロロフィルを多く含んでいるためであ る.

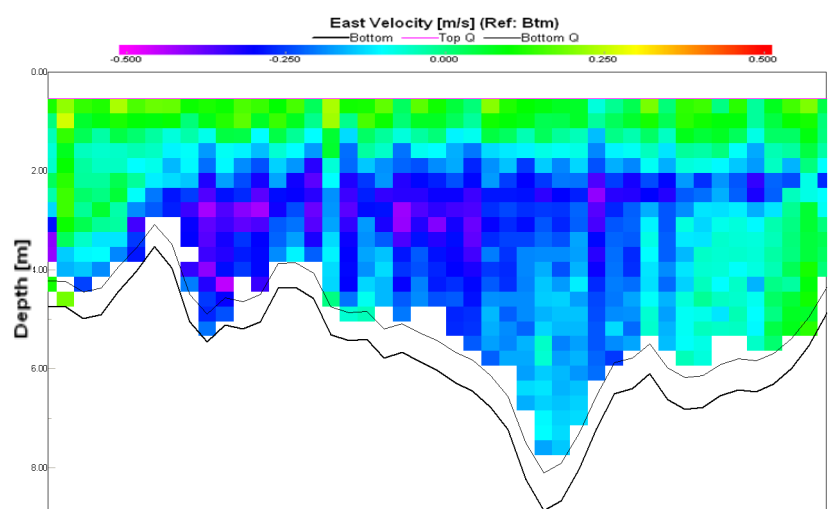

図-8＼cjkstart横断面流速分布（10月9日，上げ潮時，海門橋）

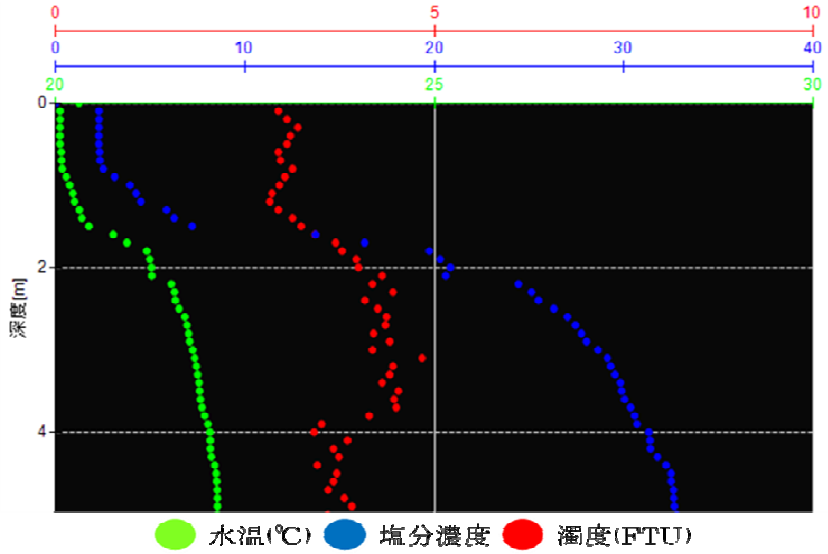

図-9＼cjkstart水温·塩分濃度·濁度の鉛直分布 （10月9日，上げ潮時，海門橋）

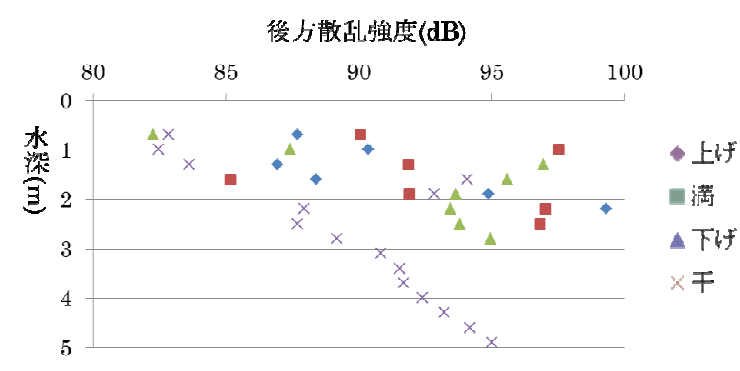

図-10 採水位置における距離補正した後方散乱強度 
図中の各セルで音波の後方散乱強度も得られており，採 水位置の該当するデータについて1分平均をとり，泉宮 $ら^{4)}$ を参考に式（1）に示す距離減衰の補正式を用いた.

$$
\sigma=I+20 \log (r)+2 a r
$$

ここに $\sigma$ : 補正後の後方散乱強度, $\mathrm{I}$ : 観測值, $\mathrm{r}$ : 卜 ランスデューサーからの距離, $\mathrm{a}$ : 補正係数である.こ こに補正係数は観測地の特性が反映されるが，ここでは 泉宮ら ${ }^{4)}$ 用いた值を参考に補正を行い，その結果が図一 10である。図-11に，採水試料を粒径・粒度分布計 LISST-100（Laser In-Situ Scatter and Transmissometry）を 用いて分析した一例を示寸. 図から，出水量がさほど大 きくないことと浮遊成分であることから，卓越粒径が $30 \mu \mathrm{m}$ 付近で非常に細かい粒子であることから, ウオッ シュロードが卓越している状況であると推測される。 こ れらのデータを積分してSS濃度を算定した。

$\mathrm{ADCP}$ の流速データにおいて，東向きの流出成分とな る位置のデータについて後方散乱強度とSS濃度の相関を 調べた結果が図-12である. 図から, 後方散乱強度が増 加すると土砂濃度が増加することを示す, 右肩上がりの 傾向を相関となることがわかる. プロットはやや頭打ち の傾向を示寸が，この原因を明らかにすることは今後の 課題である. 図-13に，同時刻・同水深の濁度計による 濁度のデータとADCPの後方散乱強度のデータの相関を 示寸. 図加 , 後方散乱強度の増加に伴って濁度も増加 する右肩上がりの関係があることがわかる. 図-12，13 の結果から得られたSS濃度と濁度の関係式を, 式 (2) に示す.

$$
\ln (\mathrm{SS})=0.5252 \ln (\mathrm{Tb})+0.4307
$$

ここで，SS:SS濃度，土砂濃度、 $\mathrm{Tb}$ :濁度である.

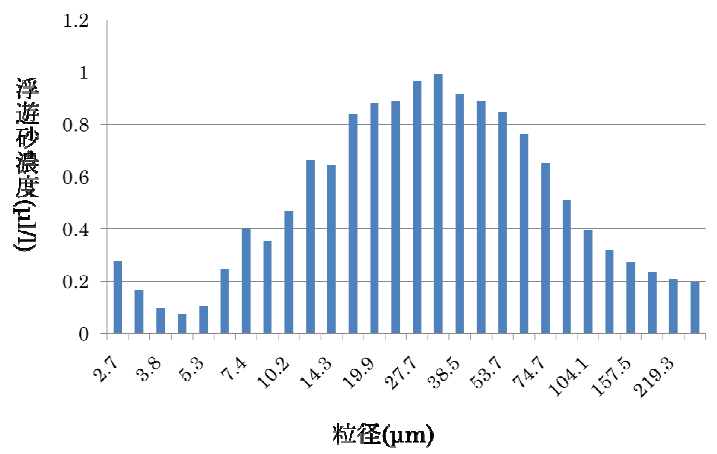

図-11 採水資料の粒径別濃度分布

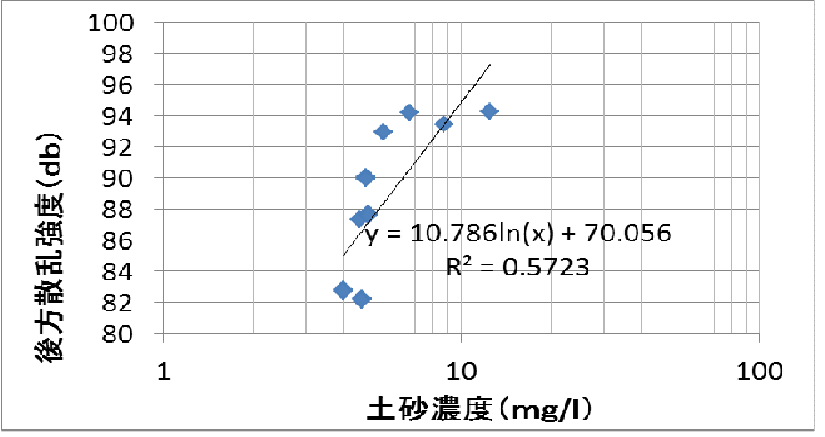

図-12 後方散乱強度と土砂濃度の関係

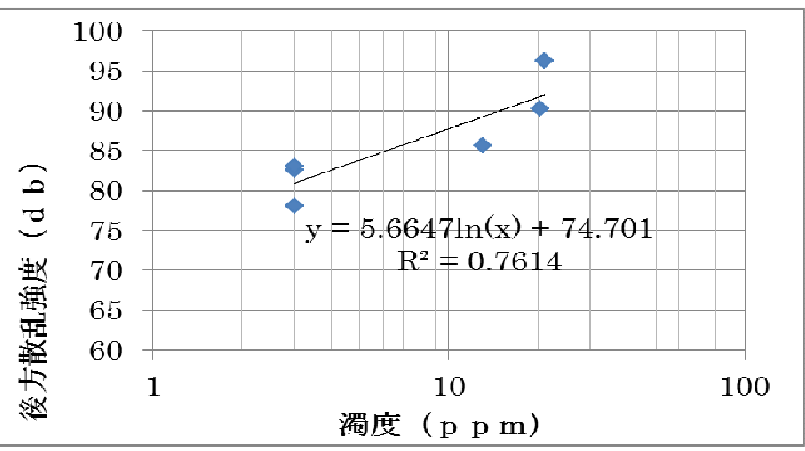

図-13 後方散乱強度と濁度の関係

\section{（3）土砂量と流量の関係}

前述したように，上げ潮時の濁度の増加のようにchl.a 濃度の上昇と一致する濁度の上昇は塩水の遡上によるも のと判断し，干潮時あるいは小出水時のみの濁度ピーク について式(2)を用いて土砂濃度に換算し，それぞれの 值に対応する流速をかけて単位時間・単位面積当たりの フラックスを求めた。 そのフラックスと流量との関係を 図-12に示寸．図から，流量が低い時と高い時で勾配の 異なる直線で近似される. 流速は流量に依存しているた め, 土砂濃度の変化によってこのような差が生じたと考 えられる。これらは土砂の生産過程に違いがあるものと 考えられるが，本論文ではそれを明らかにするまでには 至ってない，その解明は今後の課題である.

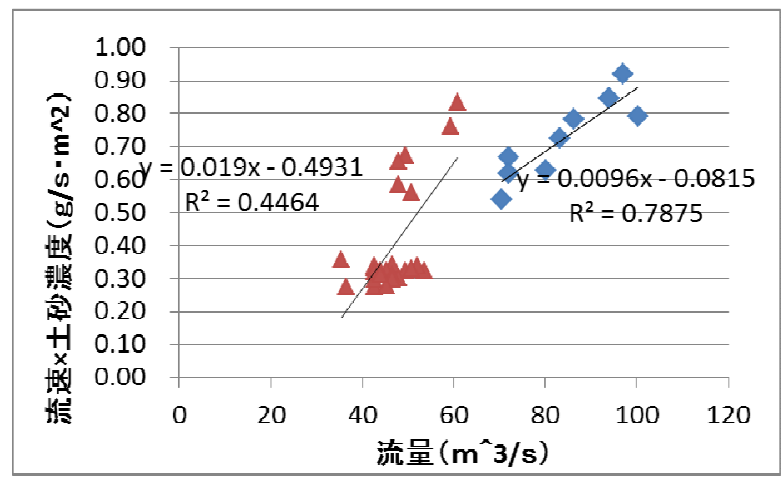

図-14 土砂フラックスと流量の関係 


\section{（4）土砂供給量の計算}

(2)の関係式より換算した土砂濃度に流量をかけて, 観測期間中の土砂供給量を計算した.

$$
\text { 土砂量 }=\mathrm{SS} \times \mathrm{Q}
$$

ここで， $\mathrm{SS}$ : 土砂濃度，Q:流量 である。

$\mathrm{ADCP}$ の観測のみから算定した結果も併せ，それらの 比較を表-3に示す．表において，「那珂川」がADCPの 観測のみから算定した結果，「本研究による算定結果」 が濁度計の長期係留データから求めた算定結果である. 表から，同程度の流量においては，土砂供給量はオー ダー的にはほぼ一致していることがわかり，いずれも妥 当な算定であることが推察される.

\section{表-3 土砂供給量の算定}

\begin{tabular}{|c|c|c|c|}
\hline & \multicolumn{2}{|c|}{ 那珂川 } & \multirow{2}{*}{$\begin{array}{c}\text { 本研究による } \\
\text { 算定結果 }\end{array}$} \\
\hline & 10月9日 & 11月13日 & \\
\hline $\begin{array}{c}\text { 流量 } \\
(\mathrm{m} \hat{3} 3 / \mathrm{s})\end{array}$ & 63.9 & 71.0 & 61.4 \\
\hline $\begin{array}{c}\text { 浮遊砂量 } \\
(\mathrm{g} / \mathrm{s})\end{array}$ & 334.8 & 774.6 & 327.5 \\
\hline
\end{tabular}

\section{（5）河口沖での土砂の挙動}

河川から供給された土砂の河口沖での挙動を検討する

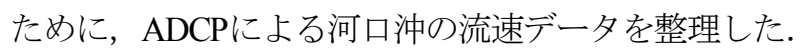
観測結果の一例として，10月9日の上げ潮時の経路を図13に示寸.アメダスの風向データからこの時間には南お よび西向きの風が吹いており，波向きも西向きであった． 流速データの一例として10月9日における水深 $0.69 \mathrm{~m}$ 地 点の東西方向の流速データを図-14に示す．観測当日は 降雨後でありやや波が高い状況であったため，船舶の動 摇の影響を抑えるために生データに移動平均をかけた。 その結果を図-15に示寸，図においては，河口沖の河口 横断方向の南向きの測線におけるデータのみを示寸. 図 から，平均的には表層において西向きの流れがあること がわかる. 図-16，17に，各水深における東西方向成分， 南北方向成分の移動平均結果を示寸，図から，観測時は 全水深にわたって西向きとともに南向きの平均的な流れ が存在していることがわかる. 従って, 総合的には南西 の大洗方向に河川水が流出していることがわかる. STD の観測結果から，観測時には表層の数 $\mathrm{cm} の$ 厚さで河川 水が流出していることがわかっている. 従って, その挙 動は表層流に依存すると考えられる．ADCPではその表 層流の見積りにはやや難点があるが，全水深で同方向の 平均流の傾向があること，ならびに那珂川河口では，北 東寄りの風によって大洗方向に濁水フロントが伸びてい る様子がしばしば確認されていることから，本観測にお

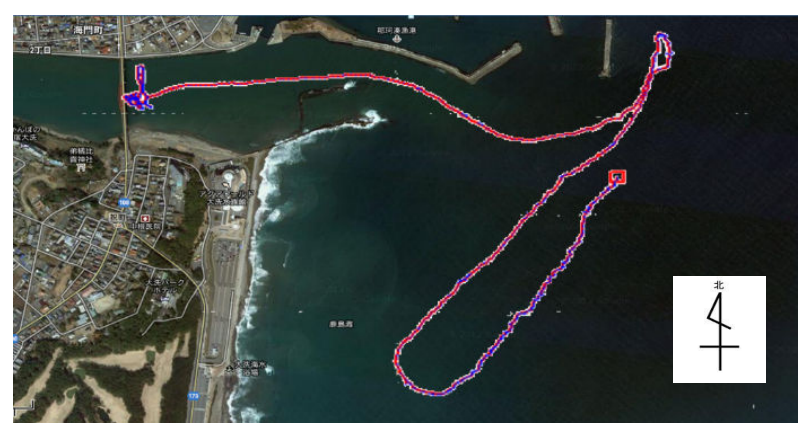

図-15 上げ潮時の観測経路（10月9日）

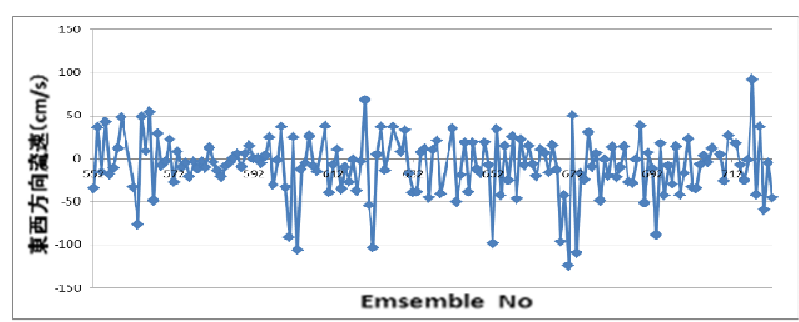

図-16 東西方向流速(水深0.69m地点)

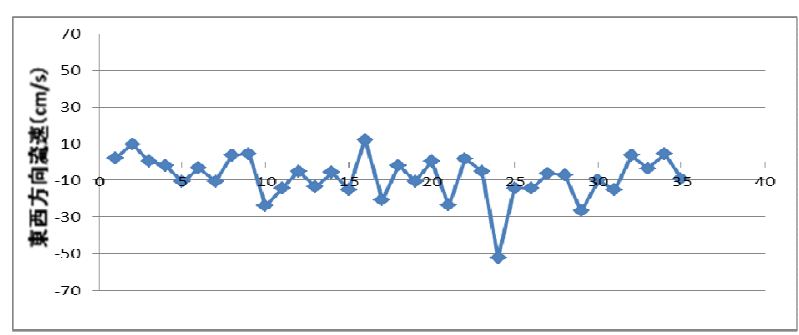

図-17 平均化した東西方向流速(水深0.69m地点)

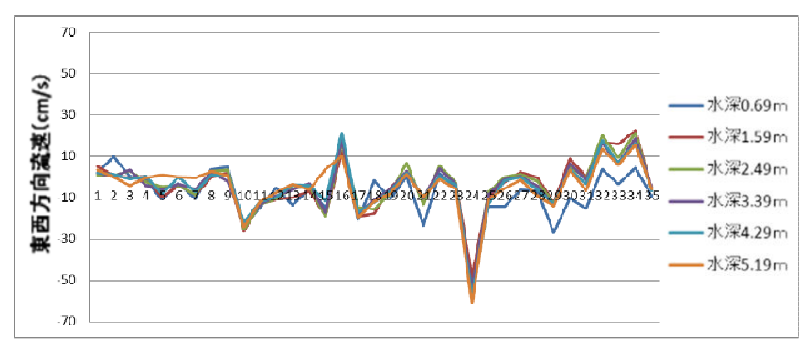

図-18＼cjkstart水深ごとの東西方向流速

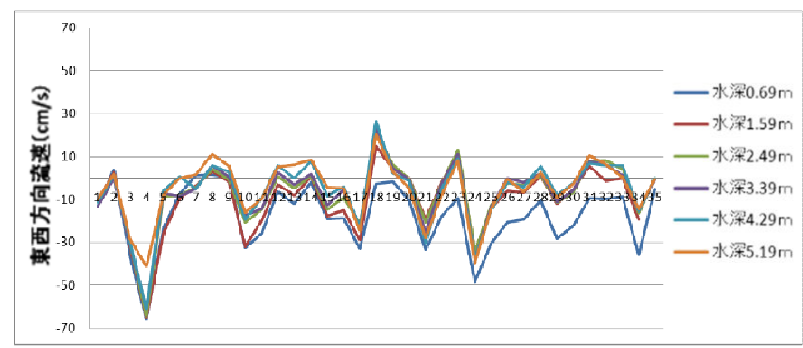

図-19＼cjkstart水深ごとの南北方向流速

いても同様に大洗方向に河川水が流出している様子がう かがえる移動平均後に残る周期的なトレンド，とくに南 北成分に顕著に認められる周期的な増減に関しては，今 
後さらに詳細な検討を行必要性がある.

\section{4. 結 論}

ADCPを用いた横断面観測と濁度計による長期係留観 測から, 那珂川からの土砂供給量の算定を試みた。本研 究で得られた主な結論を以下に示す.

(1) 那珂川河口では，塩水楔の侵入によって潮位に応 じた濁度の上昇があるが，それは同時にchl.a濃度 の上昇も引き起こす.

(2) 那須や水戸で降雨があると流量が増加し, 濁度も 増加するが, 河川水由来の濁度上昇について は, chl.濃度の上昇は起きない.

(3) LISSTによる採水試料の分析結果から，本研究に おけるADCP観測時はウォッシュロード成分が卓 越していることがわかった.

(4) $\mathrm{ADCP}$ の後方散乱強度と採水結果から, SS濃度と 後方散乱強度は正の相関がある.

(5) 濁度計による濁度とADCPの後方散乱強度も正の 相関があり，(3の結果を併用してSS濃度の算定が 可能となった.

(6) 河川水はプランクトン類が少ないと仮定し, SS濃 度を土砂濃度と考えて土砂供給量を算定すると， 同規模の流量時では，濁度計の長期係留データと $\mathrm{ADCP} ゙$ ータとの算定はほぼ同オーダーとなり， いずれも妥当な評価であることが推察された.

今後は，この結果と年間の流量データから，年間の土
砂供給量を算定するとともに，梅雨ならびに台風による 出水時のデータを用いて算定式の再評価を行い，沿岸域 の土砂動態の計算に応用していく予定である.

謝辞 : 本研究を遂行するにあたって, 国土交通省関東地 方整備局常陸河川事務所ならびに茨城県農林水産部水産 振興課には多大なご協力を頂いた．また，那珂川漁業協 同組合，那珂川第一漁業協同組合にも多大なご協力を頂 いたここに記して謝意を示寸．観測自体については茨 城海技学院ならびに茨城海上保安部に多大なご協力を頂 いた.ここに記して謝意を示す.

\section{参考文献}

1) 宇多高明 - 住谷廸夫 - 長山英樹 - 大小康弘 - 熊田貴之 （2007）：漂砂源の枯渇と護岸の前出しによって脆弱化した 海浜の異常波浪による急激な侵食, 土木学会海岸工学論文集, 第23巻, pp.1201-1206.

2) 橘田隆史・下田力・㱜田真・ Hening Huang (2010) : ADCP による河川洪水観測の先端技術と観測に際しての基礎的な技 法, 河川流量観測の新時代.

3) 重田京助・二瓶泰雄・坂井文子 - 大塚慧, 東京湾主要流入河 川における浮遊土砂輸送特性に関する基礎的検討, 土木学会 論文集B1（水工学），第52巻，pp.913-918，2008.

4) 泉宮尊司 - 國田知基・泉正寿・永松宏・石橋邦彦，船体取付 型ADCPによるシルトおよび微細砂の濃度の時空間変動の地 観測, 土木学会論文集B2 (海岸工学)，第46巻, pp.576-580, 1999.

(2013. 9. 30受付) 